\title{
MONITORING THE TREATMENT OF SEPSIS WITH VANCOMYCIN IN TERM NEWBORN INFANTS
}

José Kleber Kobol Machado, Rubens Feferbaum, Edna Maria Albuquerque Diniz, Thelma S. Okay, Maria Esther J. Ceccon and Flávio Adolfo Costa Vaz

RHCFAP/3031

MACHADO JKK et al. - Monitoring the treatment of sepsis with vancomycin in term newborn infants. Rev. Hosp. Clín. Fac. Med. S. Paulo 56(1):17-24, 2001.

A prospective study was conducted to determine if standardized vancomycin doses could produce adequate serum concentrations in 25 term newborn infants with sepsis. Purpose: The therapeutic response of neonatal sepsis by Staphylococcus sp. treated with vancomycin was evaluated through serum concentrations of vancomycin, serum bactericidal titers (SBT), and minimum inhibitory concentration (MIC).

Method: Vancomycin serum concentrations were determined by the fluorescence polarization immunoassay technique , SBT by the macro-broth dilution method, and MIC by diffusion test in agar .

Results: Thirteen newborn infants $(59.1 \%)$ had adequate peak vancomycin serum concentrations $(20-40 \mathrm{mg} / \mathrm{mL}) \mathrm{and}$ one had peak concentration with potential ototoxicity risk $(>40 \mu \mathrm{g} / \mathrm{mL})$. Only $48 \%$ had adequate trough concentrations $(5-10 \mathrm{mg} / \mathrm{mL})$, and seven $(28 \%)$ had a potential nephrotoxicity risk $(>10 \mu \mathrm{g} / \mathrm{mL})$. There was no significant agreement regarding normality for peak and trough vancomycin method (McNemar test : $\mathrm{p}=0.7905)$. Peak serum vancomycin concentrations were compared with the clinical evaluation (good or bad clinical evolution) of the infants, with no significant difference found ( $U=51.5 ; \mathrm{p}=0.1947)$. There was also no significant difference between the patients' trough concentrations and good or bad clinical evolution $(\mathrm{U}=77.0 ; \mathrm{p}=0.1710)$. All Staphylococcus isolates were sensitive to vancomycin according to the MIC. Half of the patients with adequate trough SBT (1/8), also had adequate trough vancomycin concentrations and satisfactory clinical evolution.

Conclusions: Recommended vancomycin schedules for term newborn infants with neonatal sepsis should be based on the weight and postconceptual age only to start antimicrobial therapy. There is no ideal pattern of vancomycin dosing; vancomycin dosages must be individualized. SBT interpretation should be made in conjunction with the patient's clinical presentation and vancomycin serum concentrations. Those laboratory and clinical data favor elucidation of the probable cause of patient's bad evolution, which would facilitate drug adjustment and reduce the risk of toxicity or failing to achieve therapeutic doses.

DESCRIPTORS: Physiologic monitoring. Newborn infants. Sepsis. Vancomycin. Antimicrobial susceptibility testing.

Since 1990 Staphylococcus sp., or, more precisely, the coagulase-negative Staphylococcus, has been the pathogen most commonly associated with hospital-acquired infection in neonatal intensive-care units of several countries. Until the end of the 80's coagulasenegative Staphylococcus was considered to be non-pathogenic ${ }^{1-5}$.

There is an array of difficulties in the therapy of newborns severely infected by Staphylococcus sp., the most prominent of which are the indication of antibiotic therapy, the prescribed dose, and length of its use. Therapeutic failure is due to many factors that are hardly ever measurable; such as the newborn's humoral and cellular defenses, site and severity of the infec-

From the Department of Pediatrics, Hospital das Clínicas, Faculty of Medicine, University of São Paulo. tion, the virulence of the strain, quantity of bacteria present, and the variation of serum concentrations of antimicrobial agents in vivo ${ }^{6,7,8}$. In addition, the symptoms of neonatal sepsis are discrete and/or non-specific, and include thermal disturbances (hypo or hyperthermia), respiratory distress (tachypnea, grunting, apnea), cyanosis, tachycardia, poor feeding, postprandial gastric residue, or abdominal distention ${ }^{9}$. 
The associations and changes of antibiotics, when empirically made without taking into account the patient's response, or especially, the etiologic agent, often lead to super-infections by multi-resistant bacteria and fungi.

As a result, the increased incidence of nosocomial infections by methicillin-resistant Staphylococcus sp. in neonatal intensive care units has led to an increase in the utilization of vancomycin. Its widespread use, however, has brought about the emergence of Staphylococcus $s p$, which is increasingly resistant to this drug.

To obtain success with antimicrobial therapy, it is necessary to select the appropriate antibiotic and provide the adequate dose, as well as to use the best administration technique. With the introduction of studies characterizing the parameters of antibiotic pharmacokinetics in specific populations, the usual dose of vancomycin has been demonstrated to be either insufficient or potentially toxic in many situations ${ }^{10,11}$. In this context, monitoring of both the antibiotic therapy and the newborn's clinical response becomes significantly important. Therefore, the authors' purpose was to assess whether therapy with vancomycin results in adequate serum concentrations of the antibiotic in term neonates with sepsis and to evaluate the antimicrobial therapy of neonatal sepsis caused by Staphylococcus sp., monitoring the serum vancomycin concentration, serum bactericidal titers (SBT), and minimum inhibitory concentration (MIC).

\section{METHOD}

The study population consisted of 25 term newborns admitted to the Outpatient Newborn Intensive Care Unit (ONICU), during the period from October 1995 to October 1997, with diagnoses of neonatal sepsis, all of whom received vancomycin after admission to the ONICU.

The diagnostic criteria of neonatal sepsis were based on clinical signs ${ }^{12}$, hypothermia or hyperthermia, respiratory alterations (tachypnea, grunting, apnea), cyanosis, tachycardia, poor feeding, postprandial gastric residue, or abdominal distention.

This was a prospective study, in which the authors included term newborns with gestational ages of $\geq 37$ and $<42$ weeks, based on the date of the mother's last menstrual period, with clinical and laboratory diagnoses of neonatal sepsis and suspicion of nosocomial infection caused by Staphylococcus sp.

All patients included in the sample received oxacillin and/or aminoglucosides in other services previous to the introduction of vancomycin. None of the patients included in this study presented kidney failure at the onset of treatment with vancomycin. Initially, the newborns also received antibiotic therapy for gram-negative bacteria until elucidation of the etiologic agent by means of blood culture or general cultures.

The term newborn infants with sepsis who had vancomycin suspended before completing 14 days of antibiotic therapy were excluded from the study.

The vancomycin dose administrated and intervals of administration were established according to postconceptual age ${ }^{13}$, based on the routine of the ONICU (Table 1).
The BACTEC ${ }^{\circledR}$ automated system was used to identify the infectious agent in the blood cultures. Vancomycin (VancocynÒ/Lilly) was diluted in dextrose solution at $5 \%\left(\mathrm{D}_{5} \mathrm{~W}\right)$ and administered intravenously with an infusion pump over a period of 1 hour into a peripheral vein or central catheter.

After 72 hours of antibiotic therapy with vancomycin, $0.8 \mathrm{~mL}$ blood samples were collected 1 hour after the end of infusion (serum peak) for dosing serum vancomycin concentration by the fluorescence polarization immunoassay technique (TDx/Abbott). The same procedure was performed with the sample collected 1 hour before the beginning of the next vancomycin dose, i.e. at the serum trough. The authors considered as normal or adequate values for peak serum concentration of vancomycin 20 to $40 \mathrm{mg} / \mathrm{mL}$ and trough concentration 5 to $10 \mathrm{mg} / \mathrm{mL}^{14,15}$.

For newborn infants who had Staphylococcus $s p$. isolated, the serum bactericidal titer (SBT) was also measured, both at the serum peak and trough, by the macro-broth dilution method. Trough SBT $1 / 8$ and peak SBT $1 / 16$, at the minimum, were considered adequate ${ }^{16,17}$.

In addition, the minimum inhibitory concentration (MIC) of vancomycin was analyzed in those that had Staphylococcus $s p$. isolated. The E-testÒ (AB-Biodisk), consisting of micro-diffusion test in agar, was the technique used to obtain the MIC of vancomycin. According to the criteria adopted by

Table 1 - Vancomycin dosing regimens for newborn infants ${ }^{13}$.

\begin{tabular}{ccc}
\hline Post-conceptual age (weeks) & $(\mathrm{mg} / \mathrm{Kg} / \mathrm{dose})$ & Interval (hours) \\
\hline$\leq 29$ & 20 & 24 \\
$30-33$ & 20 & 18 \\
$34-37$ & 20 & 12 \\
$38-44$ & 15 & 8 \\
$\geq 45$ & 10 & 6 \\
\hline
\end{tabular}


the National Committee for Clinical Laboratory Standard (NCCLS) ${ }^{18-22}$, an MIC $\leq 4 \mathrm{mg} / \mathrm{mL}$ was considered as susceptible, a MIC of 8 to $16 \mathrm{mg} / \mathrm{mL}$ as intermediate, and over $32 \mathrm{mg} / \mathrm{mL}^{23}$ as resistant.

With the objective of diagnosing nephrotoxicity, serum urea and creatinine were collected at the onset of treatment and 5 days after it, in accordance with the routine of the Service for dosing by automated method $\left(\mathrm{COBAS}^{\circledR}\right)$. The values considered normal were from 5 to $35 \mathrm{mg} / \mathrm{dL}$ for serum urea and from 0.4 of $0.96 \mathrm{mg} / \%$ for serum creatinine $e^{24,25}$.

With regard to treatment, the progressive disappearance of clinical signs of sepsis, according to Bone's criteria ${ }^{12}$, was considered good clinical evolution, and the permanence or worsening of clinical signs of sepsis after at least 72 hours of treatment with vancomycin was considered bad clinical evolution. When needed, patients underwent clinical intervention involving increase or decrease of vancomycin dosage, increase or decrease of the intervals between administrations, or the supply of immunotherapeutic support (plasma and immunoglobulins).

The variables studied - gestational age, post-conceptual age, patient's weight at birth and at the moment of collection, and peak and trough serum concentration of vancomycin - were analyzed by descriptive methods.

The McNemar test was performed to evaluate whether trough and peak normality levels were equivalent.

The clinical evolution variable split the sample into 2 groups, one with bad evolution and another with good evolution. The 2 groups of clinical evolution were compared with regard to the serum concentrations of vancomycin, as well as to the numeric variable (Mann-Whitney's statistical U test). The pre- and post-vancomycin administration dosages of serum urea and creatinine were evaluated by
Wilcoxon's Z Test. The authors established an a error of $5 \%$.

\section{RESULTS}

The gestational age of the newborn infants included in this study varied from 37 weeks to 41 weeks and 5 days, and the post-conceptual age from 38 weeks to 44 weeks and 5 days. The average gestational age was 38 weeks \pm 1 week; median of 39 weeks, while the average post-conceptual age was 41 weeks \pm 2 weeks, median of 41 weeks.

At the time of collection, the average weight was $3130 \mathrm{~g} \pm 861.3$, median of $3000 \mathrm{~g}$. In $9(36 \%)$ of the cases, the cultures were positive for Staphylococcus sp., $88.9 \%$ of which were Staphylococcus coagulase-negative and $11.1 \%$ were Staphylococcus aureus positive.

With regard to the susceptibility shown by the minimum inhibitory concentration (MIC), all the strains were sensitive to vancomycin in vitro, since the MIC varied from 1.0 to $3.0 \mathrm{mg} / \mathrm{mL}$ (Table 2).

In the 25 cases studied here, 22 samples were collected at the serum peak and 25 at the serum trough of vancomycin.

Serum vancomycin levels obtained at the serum peak of vancomycin varied from 5.1 to $51 \mathrm{mg} / \mathrm{mL}$, with an average of $23.9 \pm 10.8$ and median of 25.5, while those levels at the serum trough varied from 2.6 to $25 \mathrm{mg} / \mathrm{mL}$,

Table 2 - Cases with positive culture. with average of $9.4 \pm 5.8$ and median of 8.0.

Thirteen cases $(59.1 \%)$ presented adequate or normal peak serum concentrations of vancomycin.

There were 8 cases $(36.4 \%)$ with peak serum concentrations of vancomycin below $20 \mathrm{mg} / \mathrm{mL}$, while just $4.5 \%$ of the cases presented a serum concentration of vancomycin with potential risk for ototoxicity, i.e. with peaks above $40 \mathrm{mg} / \mathrm{mL}$.

With regard to concentrations at the serum trough of vancomycin, the lowest value obtained was $2.6 \mathrm{mg} / \mathrm{mL}$, and $25.0 \mathrm{mg} / \mathrm{mL}$ was the highest. The average was $9.4 \mathrm{mg} / \mathrm{mL} \pm 5.8$ and the median $8 \mathrm{mg} / \mathrm{mL}$. Nineteen cases $(76 \%)$ presented therapeutic serum levels of vancomycin. Just 12 cases (48\%), however, presented adequate or normal serum values at the trough. Sub-therapeutic levels (serum concentrations of vancomycin at the valley below $5 \mathrm{mg} / \mathrm{mL}$ ) were found in 6 cases (24\%). In 7 of the cases $(28 \%)$, there were serum concentrations above $10 \mathrm{mg} / \mathrm{mL}$, with potential risk of nephrotoxicity.

Only 5 cases $(22.7 \%)$ presented adequate peak and trough serum concentrations of vancomycin. There was, therefore, no significant agreement between normality (adequate results) determined by peak and trough of vancomycin in the evaluation by the TDx/ Abbottâ method (McNemar's Test: $\mathrm{p}=$ 0.7905 (Table 3).

Wilcoxon's Z Test was used to compare the serum levels of urea and

\begin{tabular}{clc}
\hline Cases & \multicolumn{1}{c}{ Infectious Agent } & MIC $(\mathrm{mg} / \mathrm{mL})$ \\
\hline 1 & S. coagulase negative & 1.5 \\
2 & Staphylococcus haemolyticus & 1.0 \\
4 & S. coagulase negative & 1.0 \\
7 & S. coagulase negative & 2.0 \\
17 & S. coagulase negative & 3.0 \\
18 & S. coagulase negative & 1.0 \\
20 & S. coagulase negative & 1.5 \\
21 & S. coagulase negative & 1.5 \\
25 & Staphylococcus aureus & 1.5 \\
\hline
\end{tabular}


creatinine before and after the administration of vancomycin. The results showed that the difference between the values of serum urea pre- and post-vancomycin was not statistically significant: $\mathrm{Z}=1.02 ; \mathrm{p}=0.3062$. Conversely, the difference between the values of serum creatinine, before and after the introduction of vancomycin was statistically significant: $\mathrm{Z}=2.54 ; \mathrm{p}=$ 0.0444 .

The authors compared peak serum concentration of vancomycin to the clinical evolution of the newborn infants with sepsis, using MannWhitney's U Test. There was no statistically significant difference between the values of serum peaks obtained from those with good or bad evolution: $\mathrm{U}=51.5 ; \mathrm{p}=0.1947$. (Table 4).

In addition, there was also no statistically significant difference between the values of serum valleys obtained from those with good or bad clinical evolution: $\mathrm{U}=77.0$ ); $\mathrm{p}=0.1710$. (Table 5).

It was possible to determine the serum bactericidal titers (SBT) in 6 of the patients that presented Staphylococcus $s p$-positive blood or general cultures. The SBT was not determined in all of the cases, due to flaws in collection and in the macro-broth dilution technique. Of the 6 determinations performed at both the peak and trough levels of serum vancomycin, 3 cases (50\%) presented adequate SBT at both peak and trough conditions.

The data regarding laboratory and clinical monitoring is presented in table 6 .

\section{DISCUSSION}

The few published prospective studies on neonatology or pharmacology dealing with the levels of serum concentrations of vancomycin mostly report results obtained from preterm newborn infants (30 to 36 weeks of post-conceptual age). Due to the small number of cases studied to date world-

Table 3 - Agreement between normality determined by the peak serum concentrations $(20-40 \mathrm{mg} / \mathrm{ml})$ and at the trough $(5-10 \mathrm{mg} / \mathrm{ml})$ as measured by $\mathrm{TDx} /$ Abbott $^{\circledR}$ method.

\begin{tabular}{cccc}
\hline & \multicolumn{3}{c}{ Peak } \\
\cline { 2 - 3 } Valley & Adequate $(\%)$ & Inadequate $(\%)$ & Total $(\%)$ \\
\hline Adequate & $5(22.73)$ & $6(27.27)$ & $11(50)$ \\
Inadequate & $8(36.36)$ & $3(13.64)$ & $11(50)$ \\
\hline Total & $13(59.09)$ & $9(40.91)$ & $22(100)$ \\
\hline
\end{tabular}

McNemar's Test: $\mathrm{P}=0.7905$

Table 4 - Comparison of peak serum concentration of vancomycin $(\mathrm{mg} / \mathrm{ml})$ to the newborn infants' clinical evolution with sepsis.

\begin{tabular}{lcccc}
\hline $\begin{array}{l}\text { Clinical Evolution } \\
3^{\text {rd }} \text { to } 4^{\text {th }} \text { day of } \\
\text { antibiotic therapy }\end{array}$ & Average \pm SD & Median & Minimum & Maximum \\
\hline Good $(\mathrm{n}=18)$ & $25.2 \pm 10.7$ & 27.4 & 5.1 & 51.0 \\
Bad $(\mathrm{n}=4)$ & $18.1 \pm 10.6$ & 16.4 & 8.8 & 31.0 \\
\hline & $\mathrm{U}=51.5$ & $\mathrm{p}=0.1947$ & &
\end{tabular}

Table 5 - Comparison of trough serum concentration of vancomycin $(\mathrm{mg} / \mathrm{ml})$ to the newborn infants' clinical evolution with sepsis.

\begin{tabular}{|c|c|c|c|c|}
\hline $\begin{array}{l}\text { Clinical Evolution } \\
3^{\text {rd }} \text { to } 4^{\text {th }} \text { day of } \\
\text { antibiotic therapy }\end{array}$ & Average \pm SD & Median & Minimum & Maximum \\
\hline Good $(n=20)$ & $10.2 \pm 5.8$ & 8.8 & 4.5 & 25.0 \\
\hline $\operatorname{Bad} \quad(n=5)$ & $6.2 \pm 5.2$ & 4.2 & 2.6 & 15.0 \\
\hline
\end{tabular}

Table 6 - Comparison of therapeutic serum concentration $(\mathrm{mg} / \mathrm{ml})$. trough sbt (titer), $\mathrm{mic}(\mathrm{mg} / \mathrm{ml})$, and clinical evolution in each case.

\begin{tabular}{ccccc}
\hline Cases & $\begin{array}{c}\text { Trough Serum } \\
\text { concentration } \\
(\mu \mathrm{g} / \mathrm{mL})\end{array}$ & $\begin{array}{c}\text { MIC } \\
(\mu \mathrm{g} / \mathrm{mL})\end{array}$ & $\begin{array}{c}\text { TROUGH } \\
\text { SBT }\end{array}$ & Evolution \\
\hline 1 & 25.0 & 1.5 & $1 / 16$ & Good \\
2 & 5.0 & 1.0 & $1 / 16$ & Good \\
4 & 4.2 & 1.0 & $1 / 4$ & Bad \\
7 & 8.0 & 2.0 & $1 / 2$ & Good \\
17 & 12.2 & 3.0 & $1 / 4$ & Good \\
18 & 9.3 & 1.0 & $1 / 8$ & Good \\
20 & 2.7 & 1.5 & - & Bad \\
21 & 5.5 & 1.5 & - & Good \\
25 & 6.4 & 1.5 & - & Bad (death) \\
\hline
\end{tabular}

wide, further studies in term newborns are needed ${ }^{26}$.

The authors determined vancomycin levels by the fluorescence polarization immunoassay procedure (TDx/ Abbott $\left.{ }^{\circledR}\right)$. It was employed because it is still the technique used most internationally; among its advantages are the possibility of quick analysis, the requirement for small amounts of serum samples, and its low cost.

The pharmacokinetic profile of 
vancomycin is best described by a 2 or 3 compartmental model, and it is believed that a compartmental model is adequate to describe it in the clinical practice $^{26}$. A single compartmental model has also been used in recent studies of the pharmacokinetics of vancomycin in premature infants. Although there may be shortcomings in the use of the single compartmental model, it is believed that these are not clinically significant ${ }^{27-32}$.

To determine the peak serum concentration, a sample was collected 1 hour after the end of the infusion, in order to minimize the effect of incomplete distribution of the $\operatorname{drug}^{33-35}$.

Some authors have shown greater percentages of adequate peak serum than those found in the present study, reaching as much as $92 \%$, with peak serum concentrations of vancomycin between $20-40 \mathrm{mg} / \mathrm{mL}$. These results, however, vary greatly in the literature, and most of them are from preterm infants ${ }^{36}$.

When the serum concentration of vancomycin is collected at the peak, the objective is to diagnose the potential risk for ototoxicity, although there is limited information in the literature regarding this possible toxic effect related to vancomycin in newborns ${ }^{27}$.

When the serum content of vancomycin is collected at the trough, the goal is to detect the nephrotoxic effects, as well as the adequate or subtherapeutic serum concentrations. Some authors ${ }^{14}$ consider the serum level as therapeutic when the concentration at the valley is $\geq 5 \mathrm{mg} / \mathrm{mL}$. Thus, the therapeutic serum level of vancomycin is adequate when it is $\geq 5$ and $£ 10 \mathrm{mg} / \mathrm{mL}$, or inadequate when it is above $10 \mathrm{mg} / \mathrm{mL}$ (therapeutic, but with potential risk for nephrotoxicity).

The adequate serum concentrations of vancomycin at the valley and at the peak in pediatric patients vary between 5 and 12 and between 25 and $40 \mathrm{mg} /$ $\mathrm{mL}$, respectively. Other authors, as mentioned previously, consider as adequate the serum valleys of vancomycin between 5 and $10 \mathrm{mg} / \mathrm{mL}$ and the serum peaks between $20-40 \mathrm{mg} /$ $\mathrm{mL}^{14}$.

The nephrotoxicity due to vancomycin is associated to trough serum concentrations above $30 \mathrm{mg} / \mathrm{mL}^{27}$.

When the SBT value is obtained, it is possible to correlate it to the serum concentration value of the antibiotic.

Some authors suggest that there has to be a minimum of $1 / 8$ of trough serum bactericidal titer for it is associated to efficacy in the treatment ${ }^{26}$.

Other authors report the relationship between SBT levels of $1 / 8$ at the serum trough and successful healing in $95 \%$ of the pediatric patients (with ages varying from 3 days to 12 years $)^{27}$. In our results, there was one case in which it was necessary to maintain the serum concentration of vancomycin above $12 \mathrm{mg} / \mathrm{mL}$ to obtain a trough SBT of 1/8. The SBT can demonstrate that the patient's serum is acting efficiently against the infection, but that does not necessarily mean that there is efficacy at the infection site. Examples of sites in which this can occur are bones, cerebrospinalis fluid, and pleural fluids, since the SBT measures the therapeutic action of the serum against the bacteria in vitro, not at the infection site.

With regard to clinical follow-up, there are no studies with term infants in the literature that analyze the direct effect of concentrations of vancomycin and patients' clinical responses. There are also few studies that correlate MIC, SBT, and rates of cure ${ }^{14,37-39}$.

However, if the therapeutic objective is a $20-40 \mathrm{mg} / \mathrm{mL}$ range of peak serum concentration of vancomycin, that would result in peak serum values 20 times greater than the MIC and trough values 5 to 8 times greater than the $\mathrm{MIC}^{36}$.

By definition, if the trough serum concentration of the antibiotic is 4 to
8 times greater than the MIC, it means that the vancomycin has reached therapeutic tissue concentration.

Considering only the patients with adequate peak serum vancomycin concentrations, the concentration varied from 13 to 20.7 times the MIC; in the patients with adequate trough serum levels, the concentration varied from 4 to 9.3 times the MIC. The latter values are close to those found in the existing literature.

The lack of standardization of the dosage or of concern for the individual patient often results in undesirable pharmacokinetic effects, which results in the action of the drug being therapeutically ineffective.

Therapy with potent drugs becomes safer and more effective in the neonatal period when the dose is adjusted to the needs and tolerance of each newborn, since there are individual differences regarding the bioavailability of the dose used, host factors, weight and general conditions of the patient, distribution through compartments and fluids, links to inactive sites, metabolizing rate, and renal excretion. All of these determining factors undergo individual and temporal variations.

\section{CONCLUSIONS}

Recommended vancomycin doses for term treatment of newborn infants have to be based on individual weight and especially on the post-conceptual age. A standardized dose should be used only to start the antimicrobial therapy in cases of neonatal sepsis; the dose must be individualized and corrected after the measurement of the serum level of vancomycin, which is the indispensable requirement for correction of the antibiotic dose.

Kidney function must be monitored before and during the administration of vancomycin. In cases in which kidney failure is observed, the first step is to 
lengthen the intervals between the doses of vancomycin to achieve a lower frequency of administration while maintaining the same vancomycin concentration at the serum peak.

Although the study sample was small, the authors concluded that the SBT must be analyzed in conjunction with the patient's clinical evaluation and the measurements of the serum concentration values of vancomycin. The MIC must always be part of the antibiogram in order to quantify the susceptibility of the Staphylococcus sp. and to obtain the precise information regarding the intermediate or the van- comycin-resistant strains. The use of these laboratory data in association with clinical observations facilitates the adjustment of the dose and decreases the probability of toxic or sub-therapeutic effects, favoring the successful treatment of the newborn.
MACHADO JKK e col. - Monitorização da terapêutica com vancomicina em recém-nascidos de termo com sepse, utilização e importância clínica. Rev. Hosp. Clín. Fac. Med. S. Paulo 56(1):17-24, 2001.

Foi realizado um estudo prospectivo para verificar se as doses habituais de vancomicina determinam concentrações séricas adequadas em 25 recém - nascidos de termo com sepse.

Objetivos: Avaliou-se a resposta terapêutica da sepse neonatal por Staphylococcus sp., tratada com vancomicina, monitorizando além de sua concentração sérica, o poder bactericida do soro (PBS) e a concentração inibitória mínima (MIC).

Método: Os níveis séricos do antibiótico foram obtidos através do imunoensaio por fluorescência polarizada, o MIC através de micro-difusão em ágar, e o PBS foi obtido por macrodiluição em caldo.
Resultados: Concentrações séricas no pico de vancomicina adequadas (20-40 mg/mL) ocorreram em 59,1\% dos casos e um recém-nascido apresentou potencial risco de ototoxicidade (>40 mg/mL). Em $48 \%$ dos pacientes ocorreram vales séricos adequados (5$10 \mathrm{mg} / \mathrm{mL})$ e $28 \%$ dos pacientes apresentaram potencial risco de nefrotoxicidade $(>10 \mathrm{mg} / \mathrm{mL})$. Não houve concordância significante entre a normalidade determinada pelo pico e vale de vancomicina no método (prova de McNemar: $p=0,7905$ ). A concentração sérica no pico de vancomicina foi comparada com a evolução clínica dos recém-nascidos com sepse neonatal, não havendo diferença estatisticamente significante entre os picos séricos dos pacientes que apresentaram boa e má evolução (U=51,5; $\mathrm{p}=0,1947)$. Também não houve diferença estatisticamente significante entre os vales séricos dos pacientes que apresentaram boa e má evolução clíni- ca ( $U=77,0 ; p=0,1710)$. Todos os MICs obtidos demonstraram sensibilidade à vancomicina. Metade dos pacientes que apresentou PBS no vale adequado (1/8), também tiveram concentração sérica de vancomicina adequada e boa evolução clínica.

Conclusões: A recomendação de doses de vancomicina para recém-nascidos de termo deve ser baseada no peso e na idade pós-conceptual apenas para dar início à terapia antimicrobiana na sepse neonatal, não existindo um padrão de doses ideal. Logo, a dose deve ser individualizada. A utilização desses dados laboratoriais com a clínica favorecem a elucidação da provável causa da má evolução do paciente, facilitando o ajuste da droga e a menor chance de efeitos tóxicos ou sub-terapêuticos .

DESCRITORES: Monitorização fisiológica. Recém-nascido. Sepse. Vancomicina. Teste de susceptibilidade antimicrobiana. 
1. FREEMAN J, EPSTEIN MF, SMITH NE et al. - Extra hospital stay and antibiotic usage with nosocomial coagulase-negative staphylococcal bacteremia in two neonatal intensive care unit populations. Am J Dis Child 1990; 144-324.

2. GRUSKAY JA, NACHAMKIN I, BAUMGART $S$ et al. - Predicting the pathogenicity of coagulase-negative Staphylococcus in the neonate: Slime production, antibiotic resistance and predominance of S. epidermidis species. Pediatr Res 1986; 20:397A.

3. GUNN BA - Comparative virulence of human isolates of coagulasenegative staphylococci tested in an infant mouse weight retardation model. J Clin Microbiol 1989; 27:507.

4. HALL RT, HALL SL, BARNES WG et al. - Characteristics of coagulase-negative Staphylococci from infants with bacteremia. Pediatr Infect Dis J 1987; 6:377.

5. MARTIN MA, PFALLER MA \& WENZEL RP - Coagulase-negative staphylococcal bacteremia. Mortality and hospital stay. Ann Intern Med 1989; 110: 9.

6. BALEY JE \& FANAROFF AA - Neonatal infections, part 2: Specific infectious diseases and therapies. In: SINCLAIR JC \& BRACKEN MB - Effective care of the newborn infant. Oxford, Oxford, University Press, 1992. p.477-50.

7. COLE FS - Bacterial infections of the newborn. In: TAEUSCH HW, BALLARD RA \& AVERY ME - Schaffer and Avery's Diseases of the Newborn. $6^{\text {th }}$ ed. Philadelphia, Saunders, 1991. p. 350369.

8. KLEIN JO \& MARCY SM - Bacterial sepsis and meningitis. In: REMMINGTON JS \& KLEIN JO - Infectious diseases of the fetus and newborn infant. $4^{\text {th }}$ ed. Philadelphia, Saunders, 1990. p. 601-656.

9. GINOVART GG, ANDREU DMD, FANE RR et al. - Sepsis caused by coagulase-negative Staphylococcus in the newborn infant. Clinical and therapeutic aspects. An Esp Pediatr 1993; 38 (6):48892.

10. RODVOLD KA, EVERETT JA, PYKA JA et al. - Pharmacokinetics and administration regimes of vancomycin in neonates, infants and children. Clin Pharmacokinet 1997; 33(1):32-51.

11.ZOKUFA HZ, RODVOLD KA, BLUM RA et al. - Simulation of Vancomycin peak and through concentrations using five dosing methods in 37 patients. Pharm 1989; 9:10.

12. BONE RC - The pathogenesis of sepsis . Ann Intern Med 1991;115: 457-469.

13. YOUNG TE \& MANGUM OB - The Manual of Drugs used in Neonatal Care. 9th ed. Raleigh, North Carolina, Acorn Pub, 1996, p. 52-53, Vancomycin.

14. SCHAAD UB, MCCRACKEN GH Jr \& NELSON JD - Clinical pharmacology and efficacy of vancomycin in pediatric patients. $\mathbf{J}$ Pediatr 1980; 96:119-26.

15. TAKETOMO CK, HODDING JH \& KRAUS DM - In: Pediatric Dosage Handbook. 3rd ed. Hudson, Cleveland Lexi, 1997, p.703-04, Vancomycin.
16. COLEMAN DL, HORWITZ RI, ANDRIOLE VT - Association between serum inhibitory and bactericidal concentrations and therapeutic outcome in bactericidal endocarditis. Am J Med 1982; 73: 260-67.

17. WOLFSON JS \& SWARTZ MN - Serum bactericidal activity as the monitor of antibiotic therapy. N Engl J Med 1985; 312:968975 .

18. NATIONAL committee for clinical laboratory standards Methodology for the serum bactericidal test: proposed guideline. NCCLS document. In: NATIONAL committee for clinical laboratory standards, Villanova, Pa., 1987. p. M21- P.

19. NATIONAL committee for clinical laboratory standards Methodology for the Serum Bactericidal Test. Tentative Standard. In: NATIONAL COMMITTEE FOR CLINICAL LABORATORY STANDARDS. Villanova, Pa., 1992. p.M21-T.

20. NATIONAL committee for clinical laboratory standards - Methods for Determining Bactericidal Activity of Antimicrobial Agents. Tentative Standard, M26-t. In: NATIONAL COMMITTEE FOR CLINICAL LABORATORY STANDARDS. Villanova, Pa., 1992. p. M26-T.

21. NATIONAL committee for clinical laboratory standards - Methods for Dilution Antimicrobial Susceptibility Testing for Bacteria that Grow Aerobically. Approved standard. In: NATIONAL COMMITTEE FOR CLINICAL LABORATORY STANDARDS. Villanova, Pa., 1993. p.M7-A3.

22. NATIONAL committee for clinical laboratory standards - Performance Standard. In: NATIONAL COMMITTEE FOR CLINICAL LABORATORY STANDARDS. Villanova, Pa., 1993. p.M2-A5.

23. CENTERS for disease control. MMWR 1997; 46:765-6.

24. JOHNSON GM, LEE DA, REGELMANN WE et al. - Interference with granulocyte function by Staphylococcus epidermidis slime. Infect Immun 1986; 54:13.

25. RUDD PT, HUGHES EA, PLATCZEK MM et al. - Reference ranges for plasma creatinine during the first month of life. Arch Dis Child 1983; 58:21

26. GABRIEL MH, KILDOO CW, GENNRICH JL et al. - Prospective evaluation of the vancomycin dosage guideline for neonates. Clin Pharm 1991; 10:129-32.

27. MATZKE GR, ZHANEL GG \& GUAY DRP - Clinical pharmacokinetics of vancomycin. Clin Pharmacokinet 1986; 11: 257-82.

28. ALPERT G, CAMPOS JM, HARRIS MC et al. - Vancomycin dosage in pediatrics reconsidered. A J D C 1984; 138:20-2.

29. BAUMGART S, HALL SE, CAMPOS JM et al. - Sepsis with coagulase-negative staphylococci in critically ill newborns. A J D C 1983; 137:461-3.

30. GROSS JR, KAPLAN SL, KRAMER WG et al. - Vancomycin pharmacokinetics in premature infants. Pediatr Pharmacol 1985; 5:17-22. 
31.JAMES A, KOREN G, MILLIKEN J et al. - Vancomycin pharmacokinetics and dose recommendations for preterm infants. Antimicrob Agents Chemother 1987; 31:52.

32. LEONARD MB, KOREN G, STEVENSON DK et al. - Vancomycin pharmacokinetics in very low birthweight neonates. Pediatr Infect Dis J 1989; 8:282.

33. NAQVI SH, KEENAN WJ, REICHELEY RM et al. - Vancomycin pharmacokinetics in small, seriously ill infants. A J D C 1986; 140:107-120.

34. KILDO CW III, LIN L, GABRIEL MH et al. - Vancomycin pharmacokinetics in infants: relationship to post-conceptional age and serum creatinine. Dev Pharmacol Ther 1990; 14:77-83.

35. REED MD, KLIEGMAN RM, WEINER JS et al. - The clinical pharmacology of vancomycin in seriously ill preterm infants. Pediatr Res 1987; 22:360.
36. GABRIEL MH \& GENNRICH JL - Vancomycin dosing for neonates. Pediatr Infect Dis J 1993; 12(2):156-7.

37. LISBY-SUTCH SM \& NAHATA MC - Dosage guidelines for the use of vancomycin based on its pharmacokinetics in infants. Eur $\mathbf{J}$ Clin Pharmacol 1988; 35:637-42.

38. LOURIA DB, KAMINSKI T \& BUCHMAN J - Vancomycin in severe staphylococcal infections. Arch Intern Med 1961; 107:225-40.

39. SORRELL TC, PACKHAM DR, SHANKER S et al. - Vancomycin therapy for methicillin-resistant Staphylococcus aureus. Ann Intern Med 1982; 97:344 -50.

Received for publication on the 27/11/00 